\title{
Living in a potentially toxic environment: comparisons of endofauna in two congeneric sponges from the Great Barrier Reef
}

\author{
Greg A. Skilleter ${ }^{1, *}$, Bayden D. Russell ${ }^{1}$, Bernard M. Degnan ${ }^{2}$, Mary J. Garson ${ }^{3}$ \\ ${ }^{1}$ Marine \& Estuarine Ecology Unit, School of Integrative Biology, ${ }^{2}$ School of Integrative Biology, and \\ ${ }^{3}$ Department of Chemistry, University of Queensland, Brisbane, Queensland 4072, Australia
}

\begin{abstract}
The abundance and community composition of the endofauna in 2 species of sponge, Haliclona sp. 1 and Haliclona sp. 2 (phylum Porifera: order Haplosclerida), were examined at different sites on the slope at Heron Island Reef, in the southern Great Barrier Reef, on 2 separate occasions. Both species of Haliclona occupy similar habitats on the reef slope and are often found living adjacent to each other, but the major groups of secondary metabolites and the gross external morphology in the 2 species of sponge are different. The 2 species of sponge supported significantly different endofaunal communities, with Haliclona sp. 2 supporting 3 to 4 times more individuals than Haliclona sp. 1. Fewer demersal zooplankton (copepods), nematodes and some peracarid crustaceans were found in Haliclona sp. 1 compared with Haliclona sp. 2. There were also differences in the numbers of spionid, nereidid and syllid polychaetes living in the 2 species of sponge. The only taxon that was more abundant in Haliclona sp. 1 than Haliclona sp. 2 was the spionid Polydorella prolifera, and this difference was only evident on 1 of the 2 occasions. The amount of free space (pores, channels, cavities) for a given weight of sponge was only $19 \%$ greater in Haliclona sp. 2 than in Haliclona sp. 1, suggesting other factors, such as the differences in the allelochemicals, may have a role in determining the numbers and types of animals living in these 2 species of sponge.
\end{abstract}

KEY WORDS: Endofauna $\cdot$ Sponges $\cdot$ Haliclona $\cdot$ Coral reefs $\cdot$ Great Barrier Reef

\section{INTRODUCTION}

Sponges are sessile filter feeders comprising a significant part of the total biomass on coral reefs, often as much as hermatypic corals (Wilkinson \& Cheshire 1989). Many species produce highly toxic secondary metabolites that have been implicated in the acquisition and maintenance of space (Jackson \& Buss 1975), deterrence of predators (Paul 1992, Chanas \& Pawlik 1995), antimicrobial actions (Paul 1992) and the prevention of biofouling (Thompson et al. 1985, Henrikson \& Pawlik 1995).

Despite the presence of potentially toxic allelochemicals in many sponges (Bakus et al. 1986, Kubanek et al. 2002), there is usually a diverse community of invertebrates living in association with sponges (see
Klitgaard 1995, Ribeiro et al. 2003, and references therein). Some of these animals attach to the surface of the sponges, but many more are found living inside the canals and spaces within the sponge and can be thought of as endofauna (Saffo 1992). Previous studies have related the composition of this endofaunal community to the availability of space within the sponge (Pearse 1950, Villamizar \& Laughlin 1991), variation in the morphology of the sponge (Koukouras et al. 1992, Klitgaard 1995) and local environmental conditions such as depth and habitat of collection (Pearse 1950, Peattie \& Hoare 1981, Westinga \& Hoetjes 1981, Ribeiro et al. 2003). The potential effects of the chemical composition of different sponges on their endofaunal community have also been noted (Villamizar \& Laughlin 1991). 
As part of a larger project examining the effects of sponge allelochemicals on the settlement and recruitment of sessile organisms on tropical coral reefs (e.g. Charan et al. 1996, Clark et al. 1998, Garson et al. 1999, Green et al. 2002, Russell et al. 2003), we have been working with 2 species of Haliclona that occupy similar habitats, often living adjacent to each other, attached to a range of live and dead substrata (Russell et al. 2003). Haliclona sp. 1 (Demospongiae: Haplosclerida, Chalinidae: Queensland Museum Voucher G304086, Charan et al. 1996) is an olive-brown, fingerlike, erect sponge found on the reef slope below $5 \mathrm{~m}$ depth (Russell et al. 2003) and is often closely associated with the branching coral Acropora nobilis. Haliclona sp. 1 contains a group of relatively non-polar nitrogenous secondary metabolites, including 4 major alkaloids, Haliclonacyclamines A to D, that are strongly bioactive (Clark et al. 1998, Garson et al. 1999, Green et al. 2002). This species also contains a symbiotic dinoflagellate, Symbiodinium sp., similar in structure to the dinoflagellate found within Acropora nobilis (S. microadriaticum), and coral nematocysts distributed between the ectosome and choanosome of the sponge (Garson et al. 1998, 1999). In contrast, Haliclona sp. 2 (Queensland Museum Voucher G312726, Clark et al. 2001) is a soft-bodied orange sponge with a similar distribution to Haliclona sp. 1, but is usually found on dead massive corals (Russell et al. 2003). The dominant bioactive chemicals in Haliclona sp. 2 are the

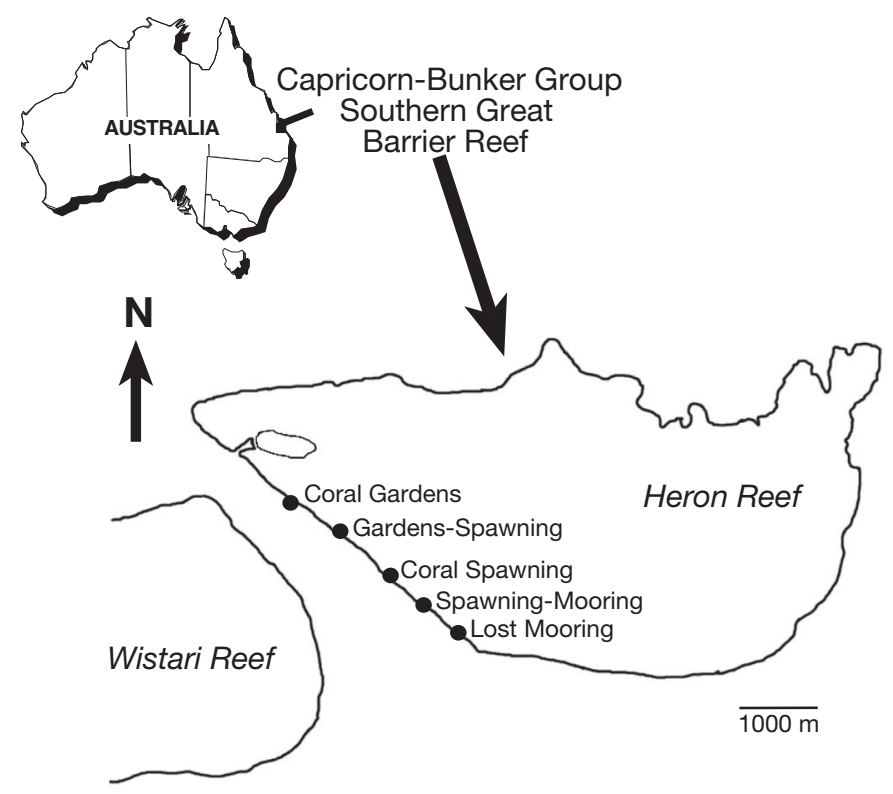

Fig. 1. Map of Australia showing position of CapricornBunker Group in the southern Great Barrier Reef and a detailed map of Heron Reef showing the relative position of the study sites from which samples of sponge were collected halaminols (HL), structurally long-chain alkyl amino alcohols (Clark et al. 2001). Haliclona sp. 2 does not contain symbiotic dinoflagellate or coral nematocysts. There is no published information on the composition of the endofaunal communities in either of these sponges, apart from mention of large numbers of the spionid polychaete, Polydorella prolifera, living in association with Haliclona sp. 2 (Clark et al. 2001).

Here, we describe the composition of the endofaunal communities from these 2 species of Haliclona. Samples were collected from a number of different sites to determine whether the composition of the endofaunal community varied from place to place as reported for other sponges (e.g. Pearse 1950, Villamizar \& Laughlin 1991, Ribeiro et al. 2003). Samples were also collected on 2 separate occasions to determine whether any temporal differences in the composition of the endofaunal communities exist in these 2 congeneric sponges.

\section{MATERIALS AND METHODS}

Study sites. All samples were collected from the reef slope on Heron Island Reef $\left(23^{\circ} 27^{\prime} \mathrm{S}, 1^{\circ} 1^{\circ} 55^{\prime} \mathrm{E}\right)$, in the Capricorn-Bunker group of the Great Barrier Reef. Sponge colonies were collected on 2 separate occasions (Period 1 = October 1998 to January 1999 and Period 2 = September 1999) to examine the composition of the endofaunal community living in association with the 2 species of sponge. In 1998/1999, samples were collected from 3 sites along the southern reef crest, in the channel between Heron and Wistari Reef (Fig. 1). Coral Gardens (Haliclona sp. 1, n =6; Haliclona sp. 2, $\mathrm{n}=5$ ) and Coral Spawning (Haliclona sp. 1, n = 9; Haliclona sp. 2, n =5) are sloping sites dominated by Acropora nobilis thickets that end in sand-dominated areas at ca. 16 to $18 \mathrm{~m}$ depth. Lost Mooring (Haliclona sp. 1, $\mathrm{n}=10$; Haliclona sp. $2, \mathrm{n}=8$ ) is a predominantly flat area consisting mainly of small $A$. nobilis thickets and small outcrops of dead massive corals. Specimens from any site were collected at the same time, but due to logistical constraints, the sites were sampled at different times over the summer. In September 1999, samples were again collected from Coral Gardens (Haliclona sp. $1 \&$ Haliclona sp. 2, n = 10) and Coral Spawning (Haliclona sp. 1 \& Haliclona sp. 2, $\mathrm{n}=10$ ), but additional samples were collected from sites intermediate between the initial 3 areas: Gardens-Spawning (Haliclona sp. 1 \& Haliclona sp. 2, $\mathrm{n}=10$ ) was ca. midway between Coral Gardens and Coral Spawning, and Spawning-Moorings (Haliclona sp. 1, n = 10; Haliclona sp. 2, n =6) was ca. midway between Coral Spawning and Lost Mooring (Fig. 1). These latter sites were examined on the second occasion to determine whether there was any consistency to the patterns of difference 
in the composition of the endofaunal community between the 2 species of sponge.

Sampling methods. Samples of sponge were collected using SCUBA. Wherever possible, samples of each species of sponge were collected in close proximity to each other, thereby ensuring that samples for the different sponges were exposed to similar environmental and ecological conditions. Samples were collected by placing a sealable plastic bag over the sponge, removing the sponge from the substratum with a flat-bladed knife, then sealing the bag. In the laboratory, the volume of each sponge was measured by removing it from the bag, allowing excess surface water to drain away for a set period of $\sim 10 \mathrm{~s}$ and then measuring the volume of seawater displaced to the nearest millilitre. The assumption here is that this short drainage time would not have been sufficient for the water in the internal spaces to escape. This measured the volume occupied by the sponge and the seawater already present in the internal pore spaces. The contents of each bag and the sponge were then fixed by transferring the sponge into a $10 \%$ solution of formalin containing ca. $0.01 \%(\mathrm{w} / \mathrm{v})$ of the stain Rose Bengal. Once fixed, each sponge was broken into smaller pieces, each approximately $1 \mathrm{~cm}^{3}$ in size, and washed across a $100 \mu \mathrm{m}$ sieve. Fauna were identified to the lowest possible taxonomic level and stored in $70 \%$ ethanol. After removal of all the endofauna, the sponge material was collected across the $100 \mu \mathrm{m}$ sieve, dried and weighed to the nearest milligram.

Statistical analysis. Differences in the overall internal (free) space of the 2 species of sponge were compared by examining the relationship between the total volume of the sponge and the dry weight of sponge tissue on the basis that this would reflect, albeit crudely, any differences in the relative volume associated with the channels, pores and cavities within the sponges (Villamizar \& Laughlin 1991, Ribeiro et al. 2003). The dry weight to volume relationship for each species of sponge was compared with a 1-factor analysis of covariance (ANCOVA), with sponge weight as the covariate, after first testing each of the assumptions, including homogeneity of regression slopes and homogeneity of error variances (Huitema 1980).

Differences in the abundance of different taxa between the 2 species of sponge and among the different sites for each of the species of sponge sampled on each occasion were analysed using 1-factor ANCOVA, with sponge volume as the covariate, after first testing each of the assumptions (as above). Unplanned multiple comparisons among adjusted means for comparisons among sites were done using the BryantPaulson-Tukey (BPT) test (Huitema 1980).

The composition of the endofaunal community in each species of sponge was compared using ANOSIM (analysis of similarity) on untransformed data using the Bray-Curtis similarity measure (Clarke 1993). Data for each taxon were standardised to the abundance per $30 \mathrm{ml}$ of sponge, to allow comparisons among sponges of different volume (size). Differences in community composition were also examined graphically using non-metric multidimensional scaling (ordination) using the Bray-Curtis similarity measure on untransformed data (Clarke 1993). The contributions of different taxa to the variation in the community compositions between the 2 species of sponge were examined using SIMPER (Clarke 1993).

\section{RESULTS}

\section{Period 1}

For a given dry weight of sponge tissue, Haliclona sp. 1 occupied a significantly smaller volume than Haliclona sp. 2 (ANCOVA, p < 0.02, Fig. 2A). Haliclona sp. 1 specimens were approximately $19 \%$ smaller in volume per unit weight than Haliclona sp. 2 specimens (Fig. 2B), suggesting that the internal spaces (canals
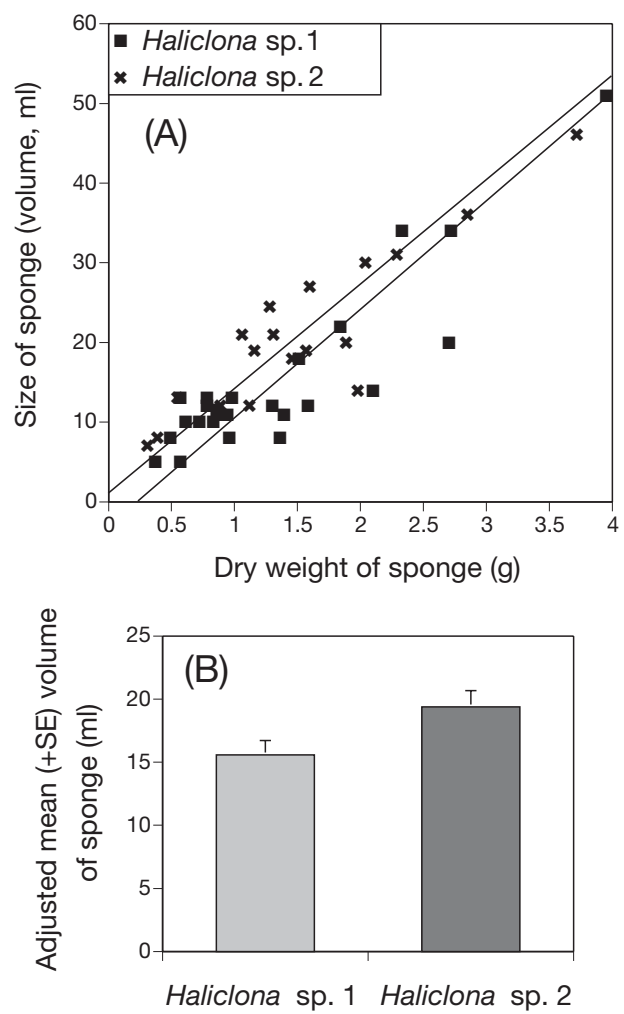

Fig. 2. Haliclona spp. (A) Volume of sponge for a given dry weight of sponge tissue. Regression slopes were not significantly different $(\mathrm{p}>0.93)$, allowing comparisons of (B) adjusted means (ANCOVA, $\mathrm{p}<0.02$ ) 

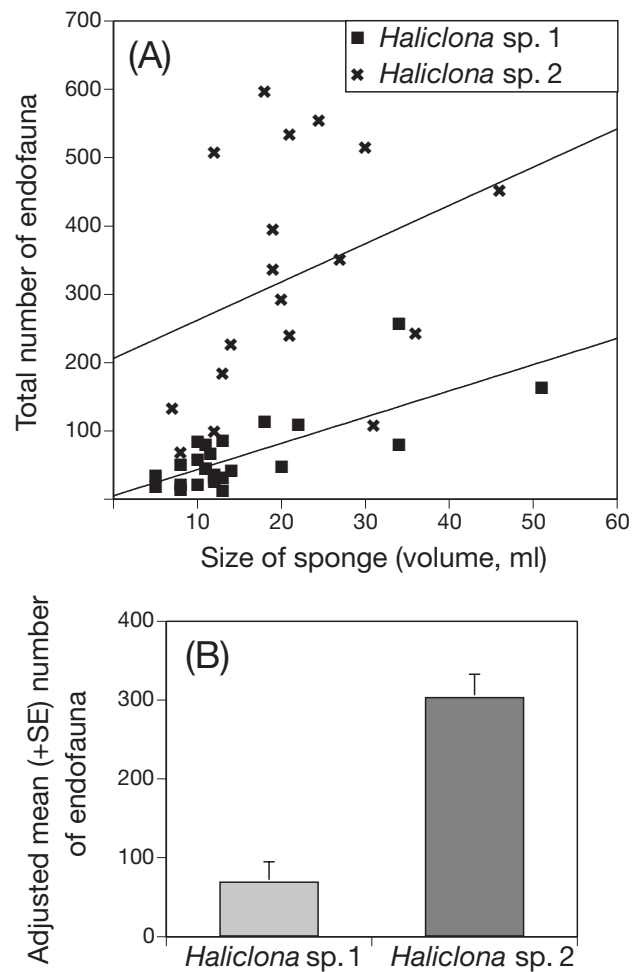

Fig. 3. Haliclona spp. (A) Total number of endofauna in sponges of different sizes (volume, ml). Regression slopes were not significantly different $(p>0.61)$, allowing comparisons of (B) adjusted means (ANCOVA, $\mathrm{p}<0.0001$ )

and pores) were either smaller or less extensive in Haliclona sp. 1 than in Haliclona sp. 2.

Haliclona sp. 2 supported significantly more endofaunal animals than Haliclona sp. 1 for a given size (volume) of sponge specimen (ANCOVA, p $<0.0001$, Fig. 3A). There were, on average, 3 times more animals living inside specimens of Haliclona sp. 2 than in similar sized specimens of Haliclona sp. 1 (Fig. 3B), based on samples collected on the first occasion. There were no significant differences in the abundance of endofauna in Haliclona sp. 2 among the 3 sites (ANCOVA, p > 0.75, Fig. 4B), but there were significantly fewer animals living in Haliclona sp. 1 specimens from Coral Spawning than from the other sites (ANCOVA, p $<0.05$, BPT tests, Fig. 4A).

The composition of the endofaunal community varied significantly between the 2 species of sponge (ANOSIM, R $=0.533, \mathrm{p}<0.001$ ), with very little overlap between the 2 sets of samples evident in the ordination (Fig. 5A). The composition of the community within Haliclona sp. 1 varied among the 3 locations, with samples collected from Coral Spawning having a significantly different community from those at the other sites (ANOSIM, p < 0.005, Fig. 5B), but there was no significant difference among the 3 locations in the

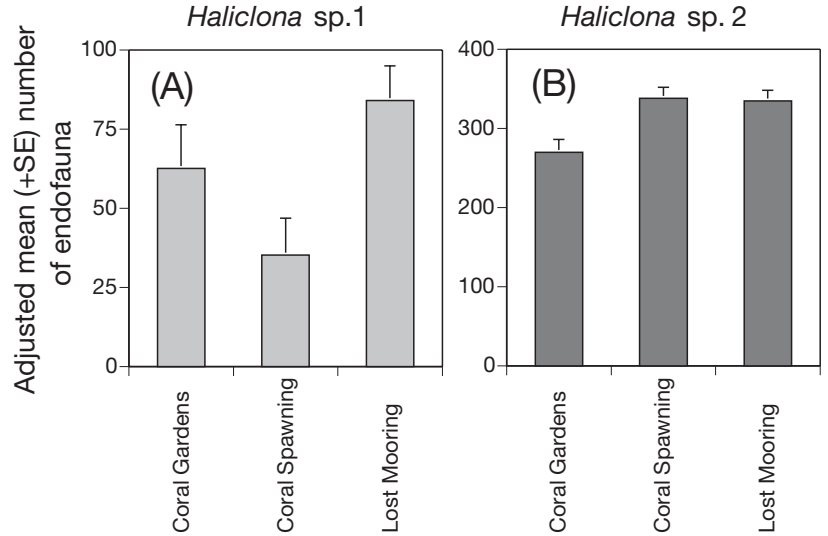

Fig. 4. Haliclona spp. Adjusted mean number of endofauna in sponges from each of the 3 different sites sampled at Time 1. Regression slopes were not significantly different (Haliclona sp. 1, p > 0.17; Haliclona sp. 2, p > 0.87), allowing comparisons of adjusted means (ANCOVA, Haliclona sp. 1, p $<0.05$; Haliclona sp. 2, p > 0.78). Note difference in scale on $y$-axes
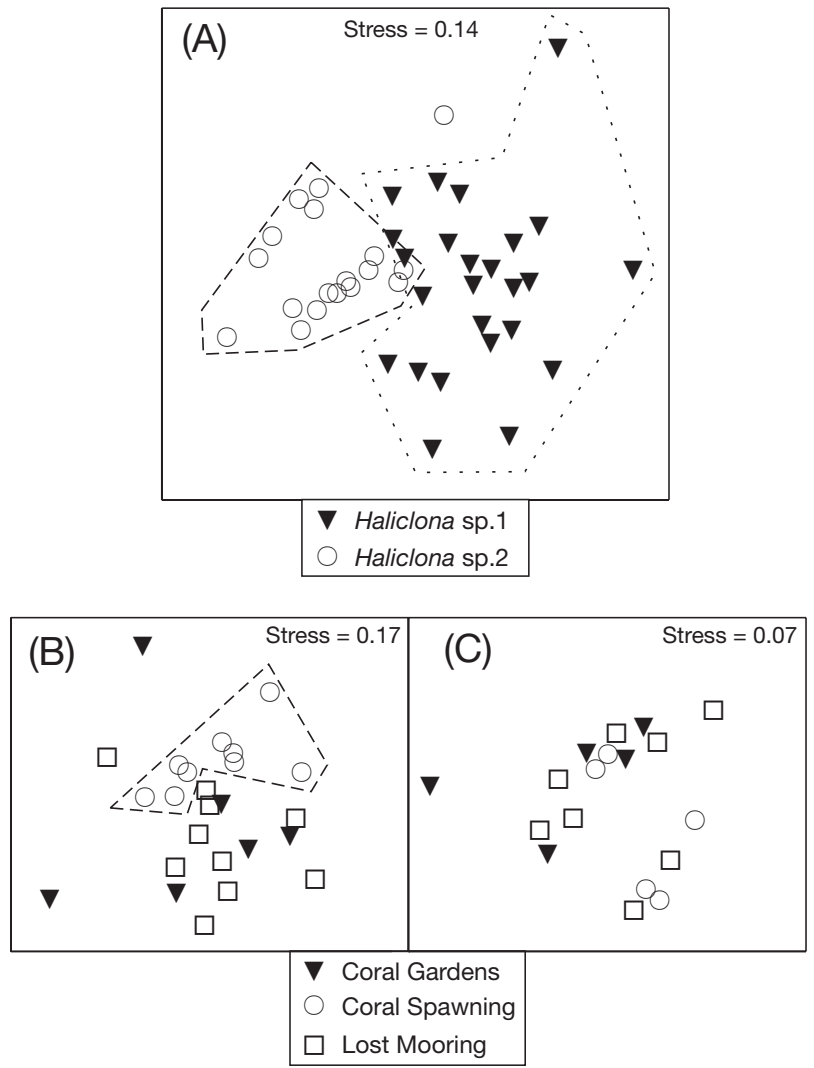

Fig. 5. Haliclona spp. Non-metric multidimensional scaling ordinations of untransformed data on the abundance of endofauna in 2 species of sponge, collected from 3 different sites on the reef slope at Heron Reef during Time 1. (A) Compares the 2 species of sponge, samples pooled across the 3 sites, (B) compares samples of Haliclona sp. 1 and (C) samples of Haliclona sp. 2, from the 3 different sites. Dashed lines represent significantly different groups in ANOSIM. Data were standardised to abundances per $30 \mathrm{ml}$ of sponge 
composition of the community within Haliclona sp. 2 (ANOSIM, p > 0.20, Fig. 5C).

Three different taxa, nematodes $(29 \%)$ and calanoid (22\%) and harpacticoid copepods (17\%), cumulatively contributed ca. $69 \%$ to the significant difference in the community composition of the 2 species of Haliclona (SIMPER analysis). Additionally, 2 groups of peracarid crustaceans, the tanaids ( $7 \%$ ) and isopods ( $7 \%$ ) were also useful in separating the 2 species of sponges in

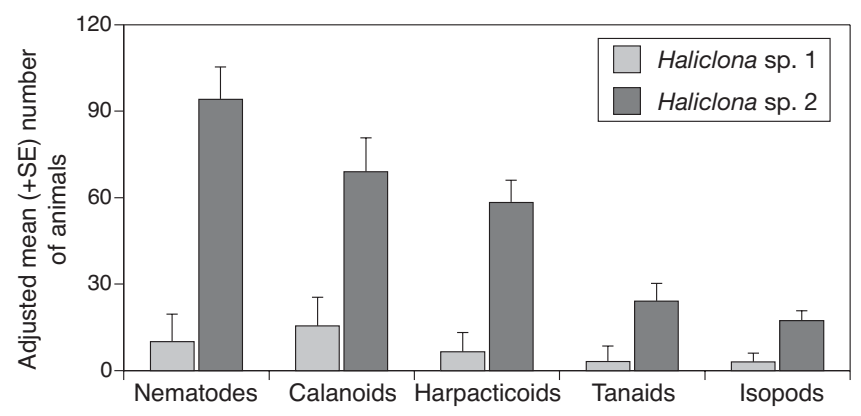

Fig. 6. Haliclona spp. Adjusted mean number of different taxa in sponges collected during Period 1. Regression slopes were not significantly different (nematodes, $\mathrm{p}>0.06$; calanoids, $\mathrm{p}>$ 0.68 ; harpacticoids, $\mathrm{p}>0.74$; tanaids, $\mathrm{p}>0.68$; isopods, $\mathrm{p}>$ 0.34 ), allowing comparisons of adjusted means (ANCOVA, $\mathrm{p}<0.01$ for all taxa)

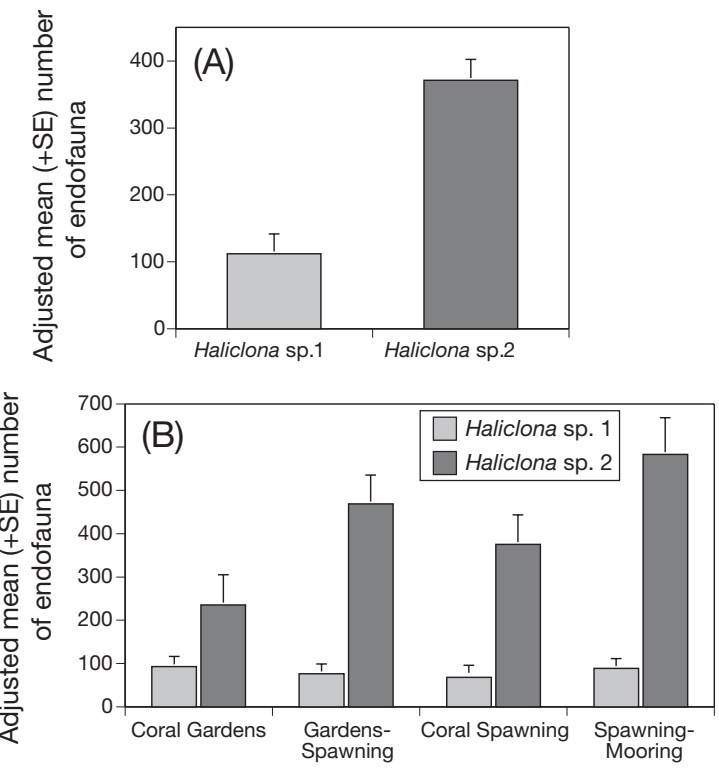

Fig. 7. Haliclona spp. (A) Total number of endofauna. Regression slopes were not significantly different $(p>0.79)$, allowing comparisons of adjusted means (ANCOVA, $\mathrm{p}<0.0001$ ). (B) Adjusted mean number of endofauna in sponges from each of 4 different sites sampled during Period 2. Regression slopes were not significantly different (Haliclona sp. 1, p > 0.66; Haliclona sp. 2, p > 0.08), allowing comparisons of adjusted means (ANCOVA, Haliclona sp. 1, p > 0.73; Haliclona sp. 2, $\mathrm{p}<0.02)$ terms of their resident endofaunal community. For all of these taxa, there were significantly more individuals found in specimens of Haliclona sp. 2 than in similar sized specimens of Haliclona sp. 1 (ANCOVA, Fig. 6). Syllid and nereidid polychaetes were also significantly more abundant in Haliclona sp. 2 than in Haliclona sp. 1 (adjusted mean \pm SE: syllids $\bar{X}_{628}=4.1 \pm 1.8 ; \bar{X}_{1031}=$ $10.7 \pm 2.2 ;$ nereidids $=\bar{X}_{628}=1.2 \pm 0.7 ; \bar{X}_{1031}=3.9 \pm$ $0.8)$, although neither of these taxa contributed $>1 \%$ to the separation of the community composition between the 2 species of sponge (SIMPER).

\section{Period 2}

Samples of Haliclona sp. 2 collected on the second occasion, from 4 different sites, again contained significantly more endofaunal animals than Haliclona sp. 1 for a given sized sponge specimen (ANCOVA, p < 0.0001), with an average a 4 -fold difference in abundance between the 2 species (Fig. 7A). In this case, there were no significant differences among the 4 sites in the adjusted mean abundance of endofauna in Haliclona sp. 1 (ANCOVA, p > 0.73; Fig. 7B), but there were differences among the sites for Haliclona sp. 2 (ANCOVA, p $<0.02$; Fig. 7B), although BPT tests were unable to distinguish specifically among the 4 sites.

The composition of the endofaunal community in sponges collected during Period 2 also varied significantly between the 2 species (ANOSIM, R $=0.591$, $\mathrm{p}<$ $0.001)$, although there was more overlap between the 2 sets of samples on this occasion (Fig. 8) compared with

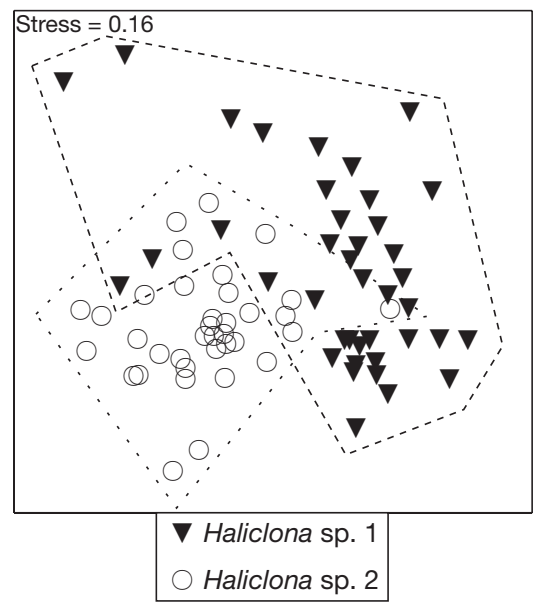

Fig. 8. Haliclona spp. Non-metric multidimensional scaling ordinations of untransformed data on the abundance of endofauna in 2 species of sponge, collected from the reef slope at Heron Reef during Period 2. Dashed lines represent significantly different groups in ANOSIM. Data were standardised to abundances per $30 \mathrm{ml}$ of sponge 


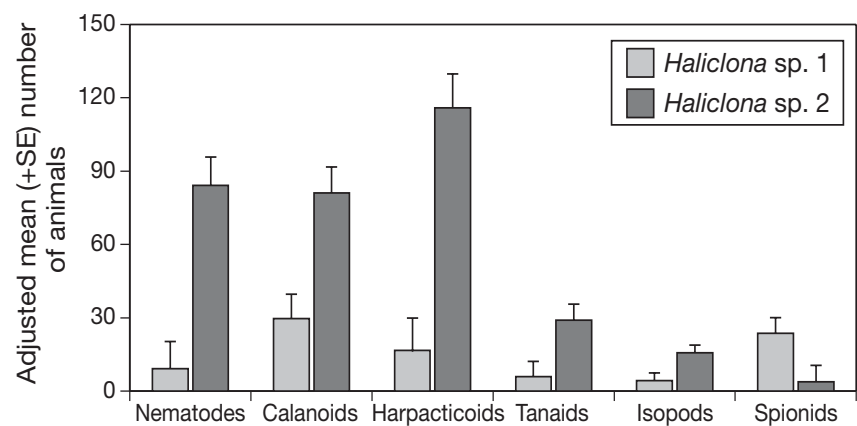

Fig. 9. Haliclona spp. Adjusted mean number of different taxa in sponges collected during Period 2. Regression slopes were not significantly different (nematodes, $\mathrm{p}>0.25$; calanoids, $\mathrm{p}>$ 0.64; harpacticoids, $\mathrm{p}>0.11$; tanaids, $\mathrm{p}>0.80$; isopods, $\mathrm{p}>$ 0.39 ; spionids, $\mathrm{p}>0.45$ ), allowing comparisons of adjusted means (ANCOVA, $\mathrm{p}<0.02$ for all taxa)

Period 1 (Fig. 5A). There was also more spatial variability among the different sponges compared with Period 1. The composition of the community within Haliclona sp. 1 varied among the 4 locations, with samples from Spawning-Mooring being significantly different from those collected at the other 3 locations (ANOSIM, $\mathrm{p}<0.001$ ). The community composition of the endofauna within Haliclona sp. 2 also varied among the 4 locations, although for this species 3 groups formed, with Gardens-Spawning and Coral Spawning not different from each other, but different from the other 2 locations, which were also different from each other (ANOSIM, p < 0.001).

Four different taxa, harpacticoid copepods (27\%), nematodes $(20 \%)$, calanoid copepods $(17 \%)$ and spionid polychaetes $(14 \%)$, contributed ca. $80 \%$ to the significant difference in the community composition of the 2 species of Haliclona collected during the second period (SIMPER analysis). Additionally, 2 groups of peracarid crustaceans, tanaids $(7 \%)$ and isopods $(5 \%)$, were also useful in discriminating between the 2 species of sponge on the basis of their endofaunal community. All of these taxa, except the spionids, were significantly more abundant in Haliclona sp. 2 than Haliclona sp. 1 (Fig. 9). The spionid Polydorella prolifera was significantly more abundant in Haliclona sp. 1 than in Haliclona sp. 2, and it was the only taxon to show this pattern in samples collected from either period.

\section{DISCUSSION}

The composition and abundance of the endofaunal community living in Haliclona sp. 1 was significantly different from that found in specimens of Haliclona sp. 2, with the main differences due to fewer demersal zooplankton (copepods), nematodes and some per- acarid crustaceans in Haliclona sp. 1. There were also differences in the abundance of some groups of polychaetes, particularly spionids (Polydorella prolifera), nereidids and syllids, although these contributed little to the overall differences in the community composition. $P$. prolifera was the only taxon that was significantly more abundant in Haliclona sp. 1, but this difference was only present in the samples collected during Period 2. Clearly, these 2 species of sponge, which are often found adjacent to each other, provide a very different internal environment from each other, reflected in the numbers and types of endofaunal animals that choose, or are able, to live inside the sponge.

Differences in the morphology between the 2 species of sponge (growth form, availability of internal space, etc.) could account for some of these differences in the composition of the endofaunal communities (e.g. Pearse 1950, Villamizar \& Laughlin 1991, Koukouras et al. 1992, Klitgaard 1995). Haliclona sp. 2 provides a greater amount of internal free space than Haliclona sp. 1, based on measures of volume to weight relationships in the 2 species, but the average difference in free space only amounted to $19 \%$, whereas there were 3 -fold differences in the number of individuals found in the 2 species of sponge. The sizes of the individual pores and channels may also differ between the 2 species of sponge, but we have no specific information on this.

Variation in morphology has also been implicated in modifying the accumulation of sediment and/or organic detritus in sponges (e.g. Dauer 1973), with this material providing an enhanced food source for some of the endofauna. This is unlikely, though, to account for the differences observed between Haliclona sp. 1 and Haliclona sp. 2. Haliclona sp. 1 has a more complex gross morphological structure than Haliclona sp. 2 , due to the presence of erect, finger-like projections, and would therefore accumulate a greater amount of particulate material (Klitgaard 1995), yet Haliclona sp. 2, with a simpler topography, supports significantly larger numbers of endofauna.

The potential role of sponge allelochemicals as attractants and inhibitors for endofauna has been noted previously (e.g. Villamizar \& Laughlin 1991, Koukouras et al. 1992), although not specifically examined. The 2 species of Haliclona examined here produce secondary metabolites that are markedly different chemically. If the allelochemicals are acting as deterrents for potential colonisers, then they are not completely effective, as both species of Haliclona were occupied by relatively large numbers of animals, albeit from a limited taxonomic range. The major groups of secondary metabolites in Haliclona sp. 1 and Haliclona sp. 2 have similar effects on the metamorphosis and survival of ascidian, Herdmania curvata, larvae in lab- 
oratory bioassays, despite operating on different developmental and molecular pathways (Green et al. 2002, Roper \& Degnan unpubl. data). The results of such bioassays may not, however, be indicative of the relative efficacy of these chemicals on other species and/or in the field, and some allelochemicals are known to be inducers for some species, but inhibitors for others (Bakus et al. 1983). The specific effects of the main secondary metabolites from these 2 species of Haliclona need to be examined for a wide range of different taxa, to determine whether there are differences in the levels and specificity of bioactivity for these allelochemicals.

Rather than inhibiting colonisation and being toxic to the endofauna, the chemically protected sponge may provide a refuge for the animals living inside the sponges. Differences in the types of bioactivity of these chemicals (i.e. the physiological or developmental pathways they impinge upon) may provide different forms and levels of protection from predators, especially for facultative species of endofauna. A wide range of tropical fishes has been reported to feed on sponges (Randall \& Hartman 1968), and secondary metabolites are thought to reduce or prevent predation on groups such as sponges (Paul 1992, Chanas \& Pawlik 1995). Groups such as amphipods gain a significant refuge from predation by living among unpalatable brown algae (Duffy \& Hay 1994), while demersal zooplankton and the juvenile stages of various peracarid crustaceans, such as isopods, are able to obtain a refuge from predation by living in structurally complex habitats, such as rubble and among live corals (Gee 1987). Chemically protected sponges may provide a similar refuge from predation, and different groups of animals may be attracted to sponges such as Haliclona through the detection of specific chemicals emanating from the potential host (Peattie \& Hoare 1981). We have no information on whether the endofauna within Haliclona sp. 1 and Haliclona sp. 2 are obligate or facultative residents, although studies on other species of sponge have reported that a large proportion of the species found in these sponges are also found elsewhere (e.g. Peattie \& Hoare 1981, Voultsiadou-Koukoura et al. 1987, Klitgaard 1995). More work is required to determine whether the endofauna from Haliclona spp. are susceptible to predators and if they obtain a refuge from living in the sponges. Other species of Haliclona have been shown to be extremely toxic to fish predators (Green 1977). Haliclona sp. 1 and Haliclona sp. 2 are both found exposed in their natural environment, a situation often associated with the presence of highly toxic chemicals that serve to deter predators (Green 1977). Sponge allelochemicals have been shown to have multiple roles (e.g. Becerro et al. 1997, Kubanek et al. 2002, and references therein); protection for endofauna may potentially be added to this increasing list.

Some of the animals living in the sponges may themselves be predators on the sponge tissue, and the 2 species of Haliclona may be more or less palatable to these animals, accounting for the observed differences in abundance and community composition between the 2 species. Syllids were significantly more abundant in Haliclona sp. 2 than in Haliclona sp. 1, and may graze on the surface of the sponge tissue (Fauchald \& Jumars 1979). The amphipod Paramphithoe hystrix has been shown to be a predator on its sponge host, Haliclona ventilabrum (Oshel \& Steele 1985), and members of the copepod genus Asterocheres feed on several different species of sponge, including Haliclona sp. (Mariani \& Uriz 2001). More work is needed to determine which, if any, species of the endofauna found in Haliclona sp. 1 and Haliclona sp. 2 are predators on their hosts and how rates of predation are affected by the production of allelochemicals by the host sponge.

There were significant differences in the abundance and community composition of the endofauna among the sites from which the samples were collected, for each of the species, although these differences were more marked in Period 2. This is consistent with numerous previous studies that have documented significant spatial variation in the composition of sponge endofauna (Pearse 1950, Peattie \& Hoare 1981, Voultsiadou-Koukoura et al. 1987, Ribeiro et al. 2003). If the allelochemicals produced by the 2 species of Haliclona have a role in determining the composition of the endofauna, then the spatial variation that was observed may be related to differences in life-history characteristics of the sponges themselves (e.g. Uriz et al. 1996). A variable rate of growth and amounts of regeneration of sponge tissue after predation, competition and disturbance have been shown to influence the distribution and concentration of sponge allelochemicals within the sponge tissue (Becerro et al. 1995, Turon et al. 1996, Uriz et al. 1996).

Differential patterns of recruitment of the endofauna to the sponges could also account for the differences in community composition among the different sites. Larval supply is often spatially and temporally variable (reviewed by Underwood \& Fairweather 1989) and, depending on when sponges were available to be colonised, different suites of larvae would likely be present in the water column (e.g. Roughgarden et al. 1988). Similarly, the abundance of demersal zooplankton is also spatially and temporally variable (Lewis \& Boers 1991), possibly providing a variable pool of potential colonisers to the sponges.

The only taxon that was significantly more abundant in Haliclona sp. 1 than in Haliclona sp. 2 was the spionid polychaete Polydorella prolifera, and this differ- 
ence was only evident in the sponges collected during Period 2, although the species was present in both species of sponge during Period 1. The large numbers of $P$. prolifera found in specimens of Haliclona sp. 1 during Period 2 may be a result of asexual reproduction of the adults already in the sponge. During Period 2, many adults were collected with intact stolons in early stages of development (e.g. Radashevsky 1996), but these were not observed during Period 1, nor were they abundant in Haliclona sp. 2. Asexual reproduction by paratomy is unusual within the Spionidae (Blake \& Kudenov 1978), although Polydorella spp. are also capable of sexual reproduction and probably have a dispersive larval stage for colonising new sponges (Radashevsky 1996). A related species, Polydorella dawydoffi, has been reported from Haliclona sp. in the south China Sea (Radashevsky 1996). It is not clear why there were fewer asexually reproducing adults in Haliclona sp. 2 than in Haliclona sp. 1, but it is possible that the bioactive secondary metabolites (halaminols) interfere with the development of the stolons. Future work will examine this in more detail.

Separating the effects of morphology and the role of allelochemicals on the composition of sponge endofauna is a challenge, which has not yet been solved. Development of an artificial sponge (or sponge mimic), capable of releasing biologically relevant concentrations of the primary bioactive allelochemicals from different sponges, while providing a suitable, standardised living environment, would allow such questions to be addressed. This could be achieved through the use of inert gels, such as phytagel (Henrikson \& Pawlik 1995), containing the appropriate allelochemicals and imbedded into a sponge matrix (G. A. Skilleter et al. unpubl. data).

Acknowledgements. We thank R. Clark, S. Litherland, L. Litherland, D. Logan, P. McCracken and K. Townsend for help in the field and the laboratory. We also acknowledge the help of the staff from the Heron Island Research Station. This research was completed under GBRMPA Permit No. G98/228 and was funded by an ARC Grant to G.A.S., B.M.D. and M.J.G., plus a Great Barrier Reef Marine Park Authority Honours Augmentative Grant to B.D.R. A draft of the manuscript was greatly improved by comments and suggestions from Simon Walker.

\section{LITERATURE CITED}

Bakus GJ, Evans T, Mading B, Kouros P (1983) The use of natural and synthetic toxins as shark repellents and antifouling agents. Toxicon Suppl 3:25-27

Bakus GJ, Targett NM, Schultze B (1986) Chemical ecology of marine organisms: an overview. J Chem Ecol 12:951-987

Becerro MA, Turon X, Uriz MJ (1995) Natural variation of toxicity in the encrusting sponge Crambe crambe (Schmidt) in relation to size and environment. J Chem Ecol 21:1931-1946

Becerro MA, Turon X, Uriz MJ (1997) Multiple functions for secondary metabolites in encrusting marine invertebrates. J Chem Ecol 23:1527-1547

Blake JA, Kudenov JD (1978) The Spionidae (Polychaeta) from southeastern Australia, and adjacent seas and islands with a revision of the genera. Mem Natl Mus Vic 39:171-280

Chanas B, Pawlik JR (1995) Defenses of Caribbean sponges against predatory reef fish. II. Spicules, tissue toughness and nutritional quality. Mar Ecol Prog Ser 127:195-211

Charan RD, Garson MJ, Brereton IM, Willis AC, Hooper JNA (1996) Haliclonacyclamines A and B, cytotoxic alkaloids from the tropical marine sponge Haliclona sp. Tetrahedron 52:9111-9120

Clark RJ, Field KL, Charan RD, Garson MJ, Brereton IM, Willis AC (1998) The haliclonacyclamines, cytotoxic alkaloids from the tropical marine sponge Haliclona sp. Tetrahedron 54:8811-8826

Clark RJ, Garson MJ, Hooper JNA (2001) Antifungal alkyl amino alcohols from the tropical marine sponge Haliclona n. sp. J Nat Prod 64:1568-1571

Clarke KR (1993) Non-parametric multivariate analyses of changes in community structure. Aust J Ecol 18:117-143

Dauer DM (1973) Polychaete fauna associated with Gulf of Mexico sponges. Fla Sci 36:192-196

Duffy JE, Hay ME (1994) Herbivore resistance to seaweed chemical defense: the roles of mobility and predation risk. Ecology 75:1304-1319

Fauchald K, Jumars PA (1979) The diet of worms: a study of polychaete feeding guilds. Oceanogr Mar Biol Annu Rev 17:193-284

Garson MJ, Clark RJ, Webb RI, Field KL, Charan RD, McCaffrey EJ (1998) The ecological role of cytotoxic alkaloids: Haliclona n. sp., an unusual sponge/dinoflagellate association. Mem Qld Mus 44:205-214

Garson MJ, Flowers AE, Webb RI, Charan RD, McCaffrey EJ (1999) An unusual sponge/dinoflagellate association in the tropical marine sponge Haliclona sp.: cellular origin of its cytotoxic components by percoll density gradient centrifugation. Cell Tissue Res 293:365-377

Gee JM (1987) Impact of epibenthic predation on estuarine intertidal harpacticoid copepod populations. Mar Biol 96: 497-510

Green G (1977) Ecology of toxicity in marine sponges. Mar Biol 40:207-215

Green KM, Russell BD, Clark RJ, Jones M, Skilleter GA, Garson MJ, Degnan BM (2002) Sponge allelochemical induces ascidian settlement but inhibits metamorphosis. Mar Biol 140:355-363

Henrikson AA, Pawlik JR (1995) A new antifouling assay method: results from field experiments using extracts of four marine organisms. J Exp Mar Biol Ecol 194:157-165

Huitema BE (1980) The analysis of covariance and its alternatives. Wiley-Interscience Press, New York

Jackson JBC, Buss L (1975) Allelopathy and spatial competition among coral reef invertebrates. Proc Natl Acad Sci USA 72:5160-5163

Klitgaard AB (1995) The fauna associated with outer shelf and upper slope sponges (Porifera, Demospongiae) at the Faroe Islands, north-eastern Atlantic. Sarsia 80:1-21

Koukouras A, Russo A, Voulsiadou-Koukoura E, Dounas C, Chintirglou C (1992) Relationship of sponge macrofauna with the morphology of their hosts in the North Aegean Sea. Int Rev Gesamten Hydrobiol 77:609-619

Kubanek J, Whalen KE, Engel S, Kelly SR, Henkel TP, Fenical W, Pawlik JR (2002) Multiple defensive roles for triterpene glycosides from two Caribbean sponges. Oecologia 131: $125-136$ 
Lewis JB, Boers JJ (1991) Patchiness and composition of coral reef demersal zooplankton. J Plankton Res 13(6): 1273-1289

Mariani S, Uriz MJ (2001) Copepods of the genus Asterocheres (Copepoda: Siphonostomatoida) feeding on sponges: behavioural and ecological traits. Invertebr Biol 120:269-277

Oshel PE, Steele DH (1985) Amphipod Paramphithoe hystrix: a micropredator on the sponge Haliclona ventilabrum. Mar Ecol Prog Ser 23:307-309

Paul VJ (1992) Chemical defenses of benthic marine invertebrates. In: Paul VJ (eds) Ecological roles of marine natural products. Cornell University Press, Ithaca, NY, p $164-188$

Pearse AS (1950) Notes on the inhabitants of certain sponges at Bimini. Ecology 31:149-151

Peattie ME, Hoare R (1981) The sublittoral ecology of the Menai Strait. II. The sponge Halichondria panicea and its associated fauna. Estuar Coast Shelf Sci 13:621-635

Radashevsky VI (1996) Morphology, ecology and asexual reproduction of a new Polydorella species (Polychaeta: Spionidae) from the South China Sea. Bull Mar Sci 58: 684-693

Randall IE, Hartman WD (1968) Sponge-feeding fishes of the West Indies. Mar Biol 1:216-225

Ribeiro SM, Omena EP, Muricy G (2003) Macrofauna associated to Mycale microstigmatosa (Porifera, Demospongia) in Rio de Janeiro State, SE Brazil. Estuar Coast Shelf Sci 57:951-959

Roughgarden J, Gaines S, Possingham H (1988) Recruitment dynamics in complex life cycles. Science 241:1460-1466

Russell BD, Degnan BM, Garson MJ, Skilleter GA (2003) Dis-

Editorial responsibility: Antony Underwood (Contributing

Editor), Sydney, Australia tribution of a nematocyst-bearing sponge in relation to potential coral donors. Coral Reefs 22:11-16

Saffo MB (1992) Invertebrates in endosymbiotic associations. Am Zool 32:557-565

Thompson JE, Walker RP, Faulkner DJ (1985) Screening and bioassays for biologically-active substances from forty marine sponge species from San Diego, California, USA. Mar Biol 88:11-21

Turon X, Becerro MA, Uriz MJ (1996) Seasonal patterns of toxicity in benthic invertebrates: the encrusting sponge Crambe crambe (Poeciloscledida). Oikos 75:33-40

Underwood AJ, Fairweather PG (1989) Supply-side ecology and benthic marine assemblages. Trends Ecol Evol 4: $16-20$

Uriz MJ, Becerro MA, Tur JM, Turon X (1996) Location of toxicity within the Mediterranean sponge Crambe crambe (Demospongiae: Poecilosclerida). Mar Biol 124:583-590

Villamizar E, Laughlin RA (1991) Fauna associated with the sponges Aplysina archeri and Aplysina lacunosa on a coral reef of the Archipelago de Los Roques National Park, Venezuela. In: Reitner J, Keupp H (eds) Fossil and recent sponges. Springer-Verlag, Berlin, p 522-542

Voultsiadou-Koukoura HE, Koukouras A, Eleftheriou A (1987) Macrofauna associated with the sponge Verongia aerophoba in the North Aegean Sea. Estuar Coast Shelf Sci 24:265-278

Westinga E, Hoetjes PC (1981) The intrasponge fauna of Spheciospongia vesparia (Porifera: Demospongiae) at Curacao and Bonaire. Mar Biol 62:139-150

Wilkinson CR, Cheshire AC (1989) Patterns in the distribution of sponge populations across the central Great Barrier Reef (Australia). Coral Reefs 8:127-134

Submitted: December 10, 2004; Accepted: June 22, 2005

Proofs received from author(s): November 8, 2005 